\title{
Exploring the relationship between polymorphisms of leptin and IGF-1 genes with milk
} yield in indicine and taurine crossbred cows

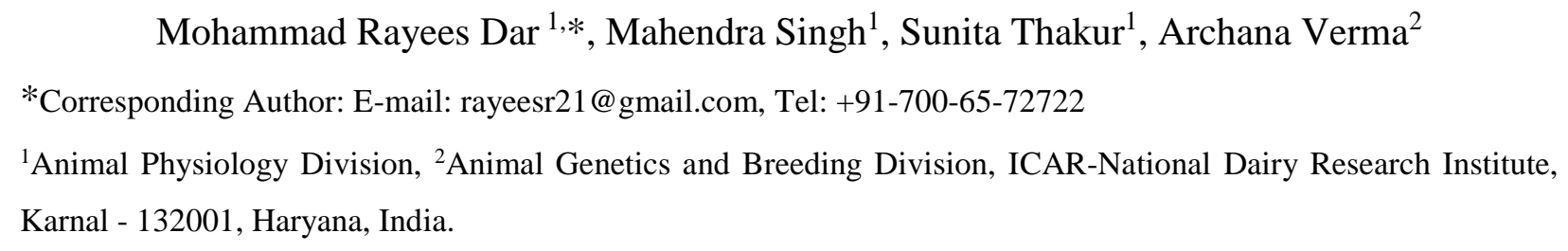

\section{ABSTRACT}

Leptin and IGF-1 plays a significant role in milk production and lactation in bovines. The present investigation was carried out to identify the novel polymorphisms in exon 3 region of leptin gene and exon $3+$ partial intron 3 of IGF-1 gene and to analyze their association with the milk production performance in indicine and taurine crossbred (Karan Fries) cows. Blood samples were collected from 160 apparently healthy Karan Fries cows. Four SNPs at positions rs29004508 (C>T), rs29004509 (C>T), rs29004510 (T>C), rs29004511 (T>C) in Leptin gene and two SNPs at positions rs133251968 (C>A), rs137289661(C>T) in IGF-1 gene were found in Karan Fries cows, however rs29004509 (C>T) had positive correlation ( $\mathrm{p}<0.05)$ with milk yield. The genetic variants observed in exon 3 region of leptin gene and their association with milk yield traits revealed the importance of CT genotype, which had been useful for genetic improvement of Karan Fries cow for milk production traits and can also be utilized as a potential genetic marker to select appropriate animals.

Key Words: Polymorphisms; Leptin; IGF-1; Genotype; Genetic marker

\section{INTRODUCTION}

In the current era of genomic informatics, attempts are increasingly underway to find certain meaningful associations in the genome that can be exploited to select animals for favorable production traits to attain rapid genetic gain in short time periods (Kiyici et al., 2019). Insulinlike growth factor-1 (IGF-1) gene is located on chromosome 5, consists of 4 exons spanning 
66191602-66264083 bp length (Laron, 2001). IGF-1, a small peptide of 70 amino acids with a

27 molecular weight of 7649 Dalton, is also considered to play an important physiological role in growth, development, metabolism and lactation in bovines (Mehmannavaz et al., 2010). IGF-1 is believed to be one of the main mediators of the effects of energy balance on the reproductive performance of the dairy cows after calving. Its concentrations are highly associated to postpartum energy balance (Mehmannavaz et al., 2010), follicular growth and resumption of ovarian cyclicity (Mullen et al., 2011; Lynch et al., 2010). SNPs, IGF1i3 A-G, IGF1i6 A-G, IGF1i7 A-G, rs29012855 A-G of IGF-1 have association $(\mathrm{P}<0.05)$ with functional survival milk protein, fat yield, somatic cell score, carcass conformation and BCS in cows (Mullen et al., 2011). SNP/SnaBI in IGF-1 with milk production traits showed no significant effects within first 4 months of lactation but a significant association with interval to commencement of luteal activity in Holstein Friesian dairy cows have been reported (Nicolini et al., 2013). SNPs, 89C/T, 98G/T and 167T/C, of IGF-1 are associated with milk production and constituent traits in buffaloes (Fatima et al., 2009). The leptin, an adipokine also plays a significant role in several physiological processes including regulation of energy balance, fertility, milk production and

41 was indicated as a candidate gene for marker assisted selection for high yielding cows (Liefers et 42 al., 2005, Vohra et al., 2011, Kononoff et al., 2017). Leptin gene is located on chromosome 7, 43 consists of 3 exons, spanning 1282412782-128257629 bp length. Only exons 2 and 3 are 44 translated, expressing 167 amino acids from which 21 amino acids as signal peptide are removed 45 to leave a 16.7 kilo Dalton protein of 146 amino acids, arranged as four anti-parallel helices (A, B, C and D), which are typical class 1 cytokines (Zhang et al., 1997). Previously an association

47 between A1457G and milk yield in British cows have been found (Banos et al., 2008; Clempson 48 et al., 2011). However, there are contradictory reports regarding association of leptin 
49 polymorphisms with composition and quality of milk (Ferreira et al., 2019). Despite the studies

50 on polymorphisms of leptin with respect to milk yield, there is no available literature on the

51 relationship of these two genes on the same aspect. The present investigation was undertaken

52 with a hypothesis that polymorphisms at the leptin and IGF-1 gene locus might play a role in

53 milk production. The associations between leptin and IGF-1 gene polymorphisms and milk yield

54 will provide insight into the underlying mechanisms of leptin and IGF-1 gene with milk

55 production, and results may be used in future breeding programs. This study was undertaken to

56 evaluate the association of single nucleotide polymorphism in bovine leptin and IGF-1 gene with

57 the milk production performance in crossbred cows.

\section{MATERIALS AND METHODS}

\subsection{Experimental animals and DNA extraction}

The present experiment was carried out in indicine and taurine crossbred (Karan Fries) lactating cows of II and III parity at NDRI, Karnal, situated at an altitude of 250 meter above mean sea level, latitude and longitude position being $29^{\circ} 42^{\prime \prime} \mathrm{N}$ and $79^{\circ} 54^{\prime \prime} \mathrm{E}$ respectively. Experiment was approved by the Institutional Animal Ethics Committee (IAEC) constituted as

64 per the article no.13 of the CPCSEA rules, laid down by Govt. of India. Crossbred Karan Fries cows $(n=160)$ were selected from the institute livestock research center of ICAR-NDRI, Karnal during the month of June. The cows were maintained in loose housing system and were fed as per the ICAR (2013) feeding standard, received green fodder and concentrate mixture as per the requirement in the ratio of 60:40. The cows were machine milked three times a day in the morning, noon and evening and the milk yields were recorded. Ten $\mathrm{ml}$ of blood was collected in EDTA coated vaccutainer tubes in morning and was stored at $-20^{\circ} \mathrm{C}$ until DNA isolation.

71 Genomic DNA was extracted from the blood samples using phenol - chloroform extraction 
72 method with minor modifications (Sambrook and Russell, 2001). The quality of DNA was

73 checked by $1.5 \%$ agarose gel electrophoresis. Quality and quantity of DNA was also estimated

74 by Biospec-nano spectrophotometer (Shimadzu co-operation, Japan). The ratio between OD $_{260}$

75 and $\mathrm{OD}_{280}$ was observed for each sample. DNA sample with a ratio of 1.8 was further diluted to a

76 final concentration of $30 \mathrm{ng} / \mu \mathrm{l}$ and was stored at $-20^{\circ} \mathrm{C}$ for further analysis.

77 2.2. Polymerase chain reaction (PCR) primers and amplifications

The primer was designed based on the bovine leptin and IGF-1 gene sequence (NCBI

79 GenBank AC_000162.1 and AC_000161.1) using Primer3 software (Table 1). The PCR reactions were carried with $25 \mu \mathrm{l}$ total volume containing template DNA of $3 \mu \mathrm{l}(30 \mathrm{ng} / \mu \mathrm{l}), 1.0 \mu \mathrm{l}$

81 of forward and reverse primer, PCR Master Mix (2x) (Fermentas) of 12.5 $\mu 1$, and $8.5 \mu 1$ of water.

82 Amplification was performed in a Thermal cycler (MJ research and BioRad, T100). The thermal

83 cycling conditions involved an initial denaturation at $95^{\circ} \mathrm{C}$ for $3 \mathrm{~min}$, followed by 35 cycles with

84 initial denaturation at $95^{\circ} \mathrm{C}$ for $30 \mathrm{~s}$, annealing temperature of $57.9^{\circ} \mathrm{C}$ and $57.3^{\circ} \mathrm{C}$ for 30 sec

85 respectively, extension at $72^{\circ} \mathrm{C}$ for 1 minute. PCR program for both the primers was similar and

86 the PCR products were detected by electrophoresis on $2 \%$ agarose gel stained with ethidium

87 bromide.

The gene and genotypic frequencies of different genotypes were estimated by standard

91 Version 9.2) as follows:

93 where,

$$
\begin{aligned}
& Y_{i j} \quad=\text { Adjusted value of milk yield of } j^{\text {th }} \text { animal of } i^{\text {th }} \text { genotype } \\
& \mu \quad=\text { Overall mean }
\end{aligned}
$$


$\mathrm{G}_{\mathrm{i}} \quad=$ Effect of $\mathrm{i}^{\text {th }}$ Genotypes

$\mathrm{e}_{\mathrm{ij}} \quad=$ Residual error $\operatorname{NID}\left(0, \sigma^{2}{ }_{\mathrm{e}}\right)$

\subsection{Analysis of sequence data association of milk yield traits with SNPs}

The PCR product with the amplicon size of 496 and 226 bp was successfully amplified,

97

98

99

100

101 allelic frequencies of leptin and IGF-1 gene are represented in table 3, respectively. cows, respectively (Figure 1,2). The final sequence of the contig for Karan Fries cows were deduced from the raw sequences by using BioEdit software. Clustal Omega software, with a reference sequence of Bos taurus (NCBI GenBank AC_000162.1 and AC_000161.1) was used for determining the polymorphism in exon 3 of Karan Fries cow. The comparison of nucleotide sequences of exon 3 of leptin and exon $3+$ partial intron 3 of IGF-1 gene with that of reference sequence of Bos taurus by Clustal Omega multiple alignments revealed 6 mutations including 5 transitions and 1 transversion. Four SNPs were found at positions rs29004508 (C>T), rs29004509 $(\mathrm{C}>\mathrm{T})$, rs29004510 $(\mathrm{T}>\mathrm{C})$, rs29004511 $(\mathrm{T}>\mathrm{C})$ in Leptin gene and two SNPs at positions rs133251968 (C>A), rs137289661(C>T) in IGF-1 gene as compared to Bos taurus (Ref. Seq. AC_000161.1 and AC_000162.1; Table 2 and Figure 3). The association of leptin and IGF-1 gene with milk yield elucidated SNP rs29004509 amplified by the primer 1 of leptin gene correspond to two genotypes CT and CC (Table 3). However, CT genotype of SNP rs29004509 had positive effect $(\mathrm{P}<0.05)$ on milk production with mean of $3827.06 \pm 145.394$ (Table 4). Rest of the identified SNPs like rs29004508 (C>T), rs29004510 (T>C), rs29004511 (T>C), rs133251968 (C>A), rs137289661(C>T) were not correlated with milk yield. The genotype and

covering exon 3 region of leptin gene and exon $3+$ partial intron 3 of $I G F-1$ gene in Karan Fries 


\section{DISCUSSION}

The present study revealed presence of four SNPs at positions rs29004508 (C>T), rs29004509 (C>T), rs29004510 (T>C), rs29004511 (T>C) in Leptin gene and two SNPs at positions rs133251968 (C>A), rs137289661(C>T) in IGF-1 gene in crossbred cows in comparison to Bos taurus. Only rs29004509 (C>T) showed positive correlation $(\mathrm{p}<0.05)$ with the milk production in Karan Fries cows. Similar to our results, Nobari et al. (2011) reported that AB genotype had a significant effect on milk production, days open and milking days compared to other genotypes in Brown Swiss cows and Liefers et al. (2002) reported that AB genotype had higher milk production in Holstein heifers. Association between polymorphism of leptin gene and milk production have been reported in several studies, leptin SNP A1457G association with milk production was found significant in cattle (Banos et al., 2008) and high producing cattle (Clempson et al., 2011). The HphI-RFLP locus had significant effect on average daily milk yield, while, Kpn2I-RFLP had significant effect on first lactation milk yield and average daily milk yield (Choudhary et al., 2019). An association of single nucleotide polymorphisms (SNP) in the leptin gene with production efficiency as well as milk protein and milk yield has been reported (Barendse et al., 2004). The association of leptin gene polymorphism with growth traits and reproduction traits has been reported in crossbred and indigenous cattle (Choudhary, 2004). GH-TaqI, LEP-Sau3AI and MYF5-TaqI polymorphisms of the genes investigated had significant effects, especially on the 305-day milk yield of Holstein cows (Sahin and Akyuz, 2017, Kiyici et al., 2019). Trakovicka, (2013) reported that the SNP LEP/Sau3AI significantly influence milk, protein and fat yield $(\mathrm{P}<0.05)$ in cows. Similarly polymorphism with respect to leptin gene was highly significant with milk yield and milk composition traits in Polish Black and White cows (Polish Friesian) (Flisikowsk et al., 2004). Lende et al., (2005) assessed that the Leptin SNP 
have association with milk yield, milk composition and DMI in dairy cows. Many SNPs were detected on the promoter region as well as exon regions of the leptin gene, and were found to be highly associated with different milk traits. Karan Fries cattle with TT genotype showed significantly higher 305 days milk yield as compared to cattle with CC genotype (Vohra et al., 2011). Other reports showed that $\mathrm{C} / \mathrm{BspEI} / \mathrm{T}$ and $\mathrm{C} / \mathrm{HphI} / \mathrm{T}$ poly-morphisms of leptin gene is associated with milk protein percentage, whereas the $\mathrm{C} / \mathrm{Hph} / \mathrm{T}$ locus of leptin is significantly associated with Solid non fat (SNF) percentage (Singh et al., 2014). Contrary to our findings, Ferreira et al. (2019) reported that polymorphisms leptin do not influence the composition and quality of milk from 1/2, 3/4 and 7/8 Holstein x Guzera cows kept in a hot climate.

Kulig and Kmiec (2009) evaluated that the selection for the A59V CC and CT animals might contribute to enhance in milk yield as well as fat and protein yields in Jersey cattle. Contrary to our findings, Mullen et al. (2011) reported that SNPs, IGF1i3 A-G, IGF1i6 A-G, IGF1i7 A-G, rs29012855 A-G, of IGF-1 are associated $(\mathrm{P}<0.05)$ with functional survival and chest width, milk protein and fat yield, milk fat concentration, somatic cell score, carcass conformation and fat. In another study, (Lynch et al., 2010) SNPs, IGFi1A-T, IGFi2C-T, IGFi3G-A, in IGF-1 were associated with milk production traits and BCS; and are in the agreement with our findings. Other studies reported that the polymorphism of bovine IGF-1 gene in exon 4 were associated with production traits in Bali cattle (Maskur et al., 2012) but polymorphism in the intron 4 of IGF-1 gene was not associated with production traits in mixed population of Charolais and Beef master cattle (Reyna et al., 2010).

It has been found that the SNP IGF-1/SnaBI with milk production traits have no significant effects on either milk yield, fat corrected milk or Total solids yield within first 4 months of lactation (Nicolini et al., 2013). In dairy cattle, some studies have analyzed the association of this 
161 SNP (IGF-1/SnaBI) with milk production traits (Hines et al., 1998; Siadkowska et al., 2006;

162 Bonakdar et al., 2010; Mehmannavaz et al., 2010; Mullen et al., 2011; Ruprechter et al., 2011).

163 Mehmannavaz et al. (2010) proved a significant effect of the SNP IGF-1/SnaBI on estimated

164 breeding values (EBV) for milk production traits in Iranian Holstein bulls, as animals with AB

165 genotype had higher EBV for milk and fat yields than homozygous genotypes. The interval from

166 calving to commencement of luteal activity postpartum (CLA) has been suggested as a suitable

167 selection criteria for fertility, as early CLA is an important factor for a new pregnancy after

168 calving, it presents higher heritability values (16 to 25\%) than traditional fertility traits, and it is

169 genetically favorably correlated with traditional fertility traits (Darwash et al., 1997; Petersson et

170 al., 2007; Nicolini et al., 2013). SNPs, 89C/T, 98G/T and 167T/C, of IGF-1 are reported to be

171 significantly associated with milk production and constituent traits in buffaloes (Fatima et al.,

172 2009).

173 CONCLUSIONS

174 In this study novel SNPs were detected in indicine and taurine crossbred cows. SNP at 175 position rs29004509 $(\mathrm{C}>\mathrm{T})$ in Leptin gene had positive correlation $(\mathrm{p}<0.05)$ with milk yield. The 176 genetic variants observed in exon 3 region of leptin gene and their association with milk yield 177 traits revealed the importance of CT genotype, which can be utilized as a potential genetic 178 marker to select elite cows for genetic improvement in future.

\section{ACKNOWLEDGMENTS}

180 The authors are thankful to the Director, National Dairy Research Institute, Karnal Haryana

181 for providing the necessary facilities to carry out this experiment. This work was supported by

182 Board of Research in Nuclear Science (BRNS) Mumbai, India under project no. 183 2013/35/48/2013-BRNS/RTAC. 


\section{AUTHOR'S CONTRIBUTIONS}

MR, MS and AV designed the study. MR and ST provided the data and performed the analysis. MR, MS and AV drafted the manuscript. MR, MS, ST and AV contributed to the interpretation of results, the discussion and commented on the manuscript. All authors read and approved the manuscript.

\section{ORCID}

rayeesr21@gmail.com http://orcid.org/0000-0002-6683-2008

chhokar.ms@gmail.com http://orcid.org/0000-0003-3541-7239

\section{REFERENCES}

Banos, G., Woolliams, J. A., Woodward, B. W., Forbes, A. B., and Coffey, M. P. (2008). Impact of single nucleotide polymorphisms in leptin, leptin receptor, growth hormone receptor and diacylglycerol acyltransferase (DGAT1) gene loci on milk production, feed and body energy traits of UK dairy cows. Journal of Dairy Science, 91, 3190-3200.

Barendse, W., Bunch, R. J., and Harrison, B. E. (2004). The leptin C73T missense mutation is not associated with marbling and fatness traits in a large gene mapping experiment in Australian cattle. Animal Genetics, 36, 86-98.

Bonakdar, E., Rahmani, H. R., Edriss, M. A., and Sayed Tabatabaei, B. E. (2010). IGF-I gene polymorphism, but not its blood concentration, is associated with milk fat and protein in Holstein dairy cows. Genetics and Molecular Research, 9, 1726-1734.

Choudhary V., Pushpendra K., Chinmoy M., Tarun K. B., Bharat B. and Arjava S., (2019). Association of leptin gene polymorphism with economic traits in crossbred cattle Indian Journal of Animal Sciences, 89(9), 974-978. 
Choudhary, V. (2004). Molecular studies on leptin and insulin-like growth factor binding protein-3 (IGFBP-3) genes in cattle, Ph.D. thesis submitted to Indian Veterinary Research Institute, Bareily, India.

Clempson, A. M., Pollott, G. E., Brickell, J. S., Bourne, N. E., Munce, N., and Wathes, D. C. (2011). Evidence that leptin genotype is associated with fertility, growth, and milk production in Holstein cows. Journal of Dairy Science, 94, 3618-3628.

Darwash, A. O., Lamming, G. E., and Woolliams, J. A. (1997). Estimation of genetic variation in the interval from calving to postpartum ovulation of dairy cows. Journal of Dairy Science, 80, 1227-1234.

Fatima, S., Bhatt, S. M., Bhong, C. D., Rank, D. N., and Joshi, C. G. (2009). Genetic polymorphism study of IGF-1 gene in buffaloes of Gujarat. Buffalo Bulletin, 28, 159-164.

Ferreira J. B., Guilhermino M. M., Leite J. H. G. M., Sousa J. E. R., Araujo B. V. S., Vasconcelos A. M., Lara M. A. C., Facanha D. A. E. (2019). Polymorphisms of leptin, $\beta$ lactoglobulin and pituitary transcription factor have no effect on milk characteristics in crossbred cows. Arquivo Brasileiro de Medicina Veterinariae Zootecnia, 71(2), 715-719.

Flisikowski K., Strzałkowska N., Słoniewski K., Krzyzewki J. and Zwierzchowski L. (2004). Association of a sequence nucleotide polymorphism in exon 16 of the STAT5A gene with milk production traits in Polish Black and White (Polish Friesian) cows. Animal Science Papers and Reports, 22, 515-522.

Hines, H. C., Ge, W., Zhao, Q., and Davis, M. E. (1998). Association of genetic markers in growth hormone and insuline-like groth factor I loci with lactation traits in Holsteins. Animal Genetics, 29, 69. 
Kadokawa, H., and Martin, G. B. (2006). A new perspective on management of reproduction in dairy cows: the need for detailed metabolic information, an improved selection index and extended lactation. Journal of Reproductive Immunology, 52, 161-168.

Kiyici, J. M., Korhan, A., Bilal, A., Mahmut, K., Esma, G. A., and Mehmet, U. C. (2019). Relationships between polymorphisms of growth hormone, leptin and myogenic factor 5 genes with some milk yield traits in Holstein dairy cows. International Journal of Dairy Technology, 72(1), 1-7.

Kononoff P. J., Defoor P. J., Engler M. J., Swingle R. S., Gleghorn J. F., James S. T. and Marquess F. L. (2017). Impacts of a leptin SNP on growth performance and carcass characters in finishing steers studied over time. Journal of Animal Science, 95(1), 194-200.

Kulig, H., and Kmiec, M. (2009). Association between leptin gene polymorphisms and growth traits in Limousin cattle. Genetika-Belgrade, 45, 838-841.

Laron, Z. (2001). Insulin-like growth factor 1 (IGF-1): a growth hormone. Molecular Pathology, 54, 311-316.

Lende, T., Te Pas, M. F. W., Veerkamp, R. F., and Liefers, S. C. (2005). Leptin gene polymorphisms and their phenotypic associations. Vitamins and Hormones, 71, 373-404.

Liefers, S. C., Veerkamp R. F. and Vanderlene T., 2002. Associations between leptin gene polymorphisms and production, live weight, gene balance, fed intake and fertility in holstein heifers. Journal of Dairy Science, 85, 1633-1638.

Liefers, S. C., Veerkamp, R. F., Te Pas, M. F. W., Chilliard, Y. and Van Der Lende, T. (2005). Genetics and physiology of leptin in periparturient dairy cows. Domestic Animal Endocrinology, 29, 227-238. 
Lynch, C. O., Mullen, M. P., Waters, S. M., Howard, D. J., O'Boyle, P., and Berry, D. P., et al. (2010). Single nucleotide polymorphisms in the growth hormone and insulin-like growth factor 1 genes are associated with production and fertility traits in dairy cows.

Maskura, Armana, C., Sumantrib, C., Gurnadib, E. and Muladno, (2012) A Novel Single Nucleotide Polymorphism in Exon 4 of Insulin-Like Growth Factor-1 Associated with Production Traits in Bali Cattle. Media Peternakan, 96-101.

Mehmannavaz, Y., Amirinia, C., Bonyadi, M., and Vaez Torshizi, R. (2010). Association of IGF-1 gene polymorphism with milk production traits and paternal genetic trends in Iranian Holstein bulls. African Journal of Microbiology Research, 4, 110-114.

Morrison, C. D., Daniel, J. A., Holmberg, B. J., Djiane, J., Raver, N., and Gertler, A., et al. (2001). Central infusion of leptin into well-fed and undernourished ewe lambs: effects on feed intake and serum concentrations of growth hormone and luteinizing hormone. Journal of Endocrinology, 168, 317-324.

Mullen, M. P., Berry, D. P., Howard, D. J., Diskin, M. G., Lynch, C. O., and Giblin, L. et al. (2011). Single Nucleotide Polymorphisms in the Insulin-Like Growth Factor 1 (IGF-1) Gene are Associated with Performance in Holstein-Friesian Dairy Cattle. Frontiers in Genetics, 2, 3.

Nicolini, P., Mariana, C., and Ana, M. (2013). Polymorphism in the insulin-like growth factor 1 gene is associated with postpartum resumption of ovarian cyclicity in Holstein-Friesian cows under grazing conditions. Acta Veterinaria Scandinavica, 55, 11.

Nobari K., Mojtaba T., Shokoufe G., Mohammad R. N., and Eisa J. (2011). Relationship between leptin polymorphism with economical traits in Iranian Sistani and Brown Swiss cows. Journal of animal and Veterianry Advances, 10(1), 1-5. 
273 Petersson, K. J., Berglund, B., Strandberg, E., Gustafsson, H., Flint, A. P., Woolliams, J.A., and

274 Royal, M.D. (2007). Genetic analysis of postpartum measures of luteal activity in dairy 275 cows. Journal of Dairy Science, 90, 427-434.

276 Reyna, X. F., Montoya, H. M., Castrellon, V. V., Rincon, A. M., Bracamonte, M. P. and Vera, W. A. (2010). Polymorphisms in the IGF1 gene and their effect on growth traits in Mexican

Ruprechter, G., Carriquiry, M., Ramos, J. M., Pereira, I., and Meikle, A. (2011). Metabolic and endocrine profiles and reproductive parameters in dairy cows under grazing conditions:

Sahin C., and Akyuz B. (2017) Detection of MYF5 gene polymorphism with PCR-RFLP method in five cattle breeds breeding in Turkey. Mediterranean Agricultural Sciences, 30, 35-38.

Sambrook, J., and Russell, D. W. (2001). Molecular cloning: A Laboratory Manual III, Cold Spring Harbor Laboratory Press, Cold Spring Harbor, New York.

Siadkowska, E., Zwierzchowski, L., Oprzadek, J., Strzalkowska, N., Bagnicka, E., and Kryzewski, J. (2006). Effect of polymorphism in IGF-1 gene on production traits in Polish Holstein-Friesan cattle. Animal Science Papers and Reports, 24:225-237.

Singh U., Deb R., Alyethodi R. R., Alex R., Kumar S., Chakraborty S., Dhama K., and Sharma A. (2014). Molecular markers and their applications in cattle genetic research: a review. Biomarkers and Genomic Medicine, 6, 49-58. maps to chromosome 4. Mammalian Genome, 7, 399-400. 
295 Trakovicka, A., Moravcikova, N., and Kasarda, R. (2013). Genetic polymorphisms of leptin and 296 leptin receptor genes in relation with production and reproduction traits in cattle. Acta 297 Biochimica Polonica, 60, 783-787.

298 Vohra V., Chakravarty A. K., Singh A., Gupta I. D., Chopra A., Dubey P. P., and Kumar D. (2011). Association of leptin gene polymorphism with 305 days milk yield in Karan Fries

301 cattle. Indian Journal of Animal Sciences, 81 (4): 388-390

Yeh, F. C., Yang, R., and Boyle, T. (1999). POPGENE VERSION 1.31: Microsoft Windowbased free Software for Population Genetic Analysis. Available from: ftp://ftp.microsoft.com/ Softlib/HPGL.EXE. 
Table 1 Primer sequences, targeted region, and amplicon sizes of bovine leptin and IGF-1 gene

\begin{tabular}{|c|c|c|c|c|c|}
\hline Gene & Sequence (5'-3') & $\begin{array}{c}\text { No. of } \\
\text { base }\end{array}$ & $\begin{array}{l}\text { Targeted } \\
\text { region on } \\
\text { gene }\end{array}$ & $\begin{array}{c}\text { Annealing } \\
\text { Temp. }\end{array}$ & $\begin{array}{c}\text { Amplicon } \\
\text { size (bp) }\end{array}$ \\
\hline \multirow[t]{2}{*}{ Leptin } & F-CCСТCTCTCCCACTGAGCTC & 20 & Exon-3 & & \\
\hline & R-TAAAGGATGCCCACATAGGC & 20 & & $57.3^{\circ} \mathrm{C}$ & 496 \\
\hline \multirow[t]{2}{*}{ IGF-1 } & F-CAGACAGGAATCGTGGATGAG & 21 & Exon $3+$ & & \\
\hline & R- TGCTGCTAAGTTGCTACAGG & 20 & $\begin{array}{c}\text { partial intron } \\
3\end{array}$ & $57.9^{\circ} \mathrm{C}$ & 226 \\
\hline
\end{tabular}

Table 2 Nucleotide changes in leptin and IGF-1 gene in Karan Fries cattle as compared to Bos taurus (NCBI Gene ID AC_000161.1 \& AC_000162.1, respectively)

\begin{tabular}{|c|c|c|c|c|c|}
\hline Gene & SNP & Location & $\begin{array}{c}\text { Nucleotide } \\
\text { Change }\end{array}$ & Type of Variation & $\begin{array}{l}\text { Amino Acid } \\
\text { Substitution }\end{array}$ \\
\hline \multirow{4}{*}{ Leptin } & rs29004508 & & $(\mathrm{C}>\mathrm{T})$ & Transition & p. $80 A>V$ \\
\hline & rs29004509 & & $(\mathrm{C}>\mathrm{T})$ & Transition & - \\
\hline & rs29004510 & Exon 3 & $(\mathrm{~T}>\mathrm{C})$ & Transition & - \\
\hline & rs29004511 & & $(\mathrm{T}>\mathrm{C})$ & Transition & - \\
\hline \multirow{3}{*}{ IGF-I } & rs133251968 & & $(\mathrm{C}>\mathrm{A})$ & Transversion & - \\
\hline & & Intron 3 & & & \\
\hline & rs137289661 & & $(\mathrm{C}>\mathrm{T})$ & Transition & - \\
\hline
\end{tabular}


Table 3 Genotypic and allelic frequencies of leptin and IGF-1 gene using sequencing in Karan Fries cattle

\begin{tabular}{|c|c|c|c|c|c|}
\hline SNP & Gene & Genotype & $\begin{array}{l}\text { Genotype } \\
\text { frequency }\end{array}$ & Allele & $\begin{array}{c}\text { Allele } \\
\text { frequency }\end{array}$ \\
\hline \multirow{3}{*}{ rs29004508 (C>T) } & \multirow{3}{*}{ Leptin } & TT & 0.1 & $\mathrm{~T}$ & 0.2 \\
\hline & & $\mathrm{CT}$ & 0.2 & \multirow{2}{*}{$\mathrm{C}$} & \multirow{2}{*}{0.8} \\
\hline & & $\mathrm{CC}$ & 0.7 & & \\
\hline \multirow{2}{*}{ rs29004509 $(\mathrm{C}>\mathrm{T})$} & \multirow{2}{*}{ Leptin } & $\mathrm{CT}$ & 0.2 & $\mathrm{~T}$ & 0.1 \\
\hline & & $\mathrm{CC}$ & 0.8 & $\mathrm{C}$ & 0.9 \\
\hline \multirow{3}{*}{ rs29004510 (T>C) } & \multirow{3}{*}{ Leptin } & $\mathrm{TT}$ & 0.65 & $\mathrm{~T}$ & 0.8 \\
\hline & & $\mathrm{CT}$ & 0.3 & \multirow{2}{*}{$\mathrm{C}$} & \multirow{2}{*}{0.2} \\
\hline & & $\mathrm{CC}$ & 0.05 & & \\
\hline \multirow{3}{*}{ rs29004511 (T>C) } & \multirow{3}{*}{ Leptin } & $\mathrm{TT}$ & 0.05 & $\mathrm{~T}$ & 0.2 \\
\hline & & $\mathrm{CT}$ & 0.30 & \multirow{2}{*}{$\mathrm{C}$} & \multirow{2}{*}{0.8} \\
\hline & & $\mathrm{CC}$ & 0.65 & & \\
\hline \multirow[t]{2}{*}{ rs133251968 (C>A) } & \multirow[t]{2}{*}{ IGF-1 } & $\begin{array}{l}\mathrm{AA} \\
\mathrm{AC}\end{array}$ & $\begin{array}{l}0.06 \\
0.44\end{array}$ & A & 0.28 \\
\hline & & $\mathrm{CC}$ & 0.5 & $\mathrm{C}$ & 0.72 \\
\hline \multirow{2}{*}{ rs137289661(C>T) } & \multirow{2}{*}{ IGF-1 } & $\mathrm{CT}$ & 0.13 & $\mathrm{~T}$ & 0.06 \\
\hline & & $\mathrm{CC}$ & 0.87 & $\mathrm{C}$ & 0.94 \\
\hline
\end{tabular}

334 Table 4 Effect of polymorphism of leptin and IGF-1 gene on average milk yield in different genotypes

\begin{tabular}{|c|c|c|c|}
\hline SNP & Genotype & Average milk yield (Kg) & p-value \\
\hline \multirow{3}{*}{ rs29004508 $(\mathrm{C}>\mathrm{T})$} & TT & $3587.19 \pm 153.04$ & \multirow{3}{*}{0.899} \\
\hline & CT & $3882.20 \pm 290.08$ & \\
\hline & $\mathrm{CC}$ & $3746.27 \pm 289.59$ & \\
\hline \multirow{3}{*}{ rs29004509 $(\mathrm{C}>\mathrm{T})$} & $\mathrm{CT}$ & $3827.06^{\mathrm{a}} \pm 145.39$ & \multirow{3}{*}{0.021} \\
\hline & $\mathrm{CC}$ & $3280.22^{b} \pm 242.99$ & \\
\hline & TT & $3642.67 \pm 528.71$ & \\
\hline \multirow[t]{2}{*}{ rs29004510 $(\mathrm{T}>\mathrm{C})$} & CT & $3599.12 \pm 193.18$ & \multirow[t]{2}{*}{0.162} \\
\hline & $\mathrm{CC}$ & $3753.37 \pm 169.62$ & \\
\hline \multirow{3}{*}{ rs29004511 (T>C) } & TT & $3753.33 \pm 169.62$ & \multirow{3}{*}{0.162} \\
\hline & $\mathrm{CT}$ & $3599.12 \pm 193.18$ & \\
\hline & $\mathrm{CC}$ & $3642.67 \pm 528.71$ & \\
\hline \multirow{3}{*}{ rs133251968 (C>A) } & AA & $3836.63 \pm 201.80$ & \multirow{3}{*}{0.521} \\
\hline & $\mathrm{AC}$ & $3211.43 \pm 277.11$ & \\
\hline & $\mathrm{CC}$ & $3073.50 \pm 465.40$ & \\
\hline \multirow{2}{*}{ rs $137289661(\mathrm{C}>\mathrm{T})$} & $\mathrm{CT}$ & $3551.92 \pm 180.98$ & \multirow{2}{*}{0.453} \\
\hline & $\mathrm{CC}$ & $3539.57 \pm 296.18$ & \\
\hline
\end{tabular}




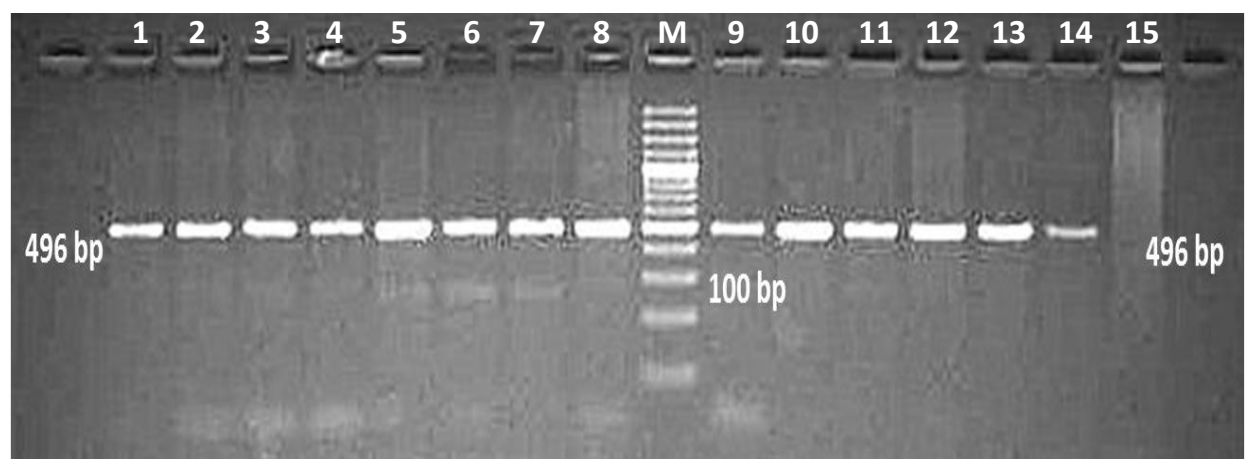

Figure 1: PCR amplification of Exon 3 of leptin gene in Karan Fries cow (M=100bp)

Lanes 1-15 = 496 bp,

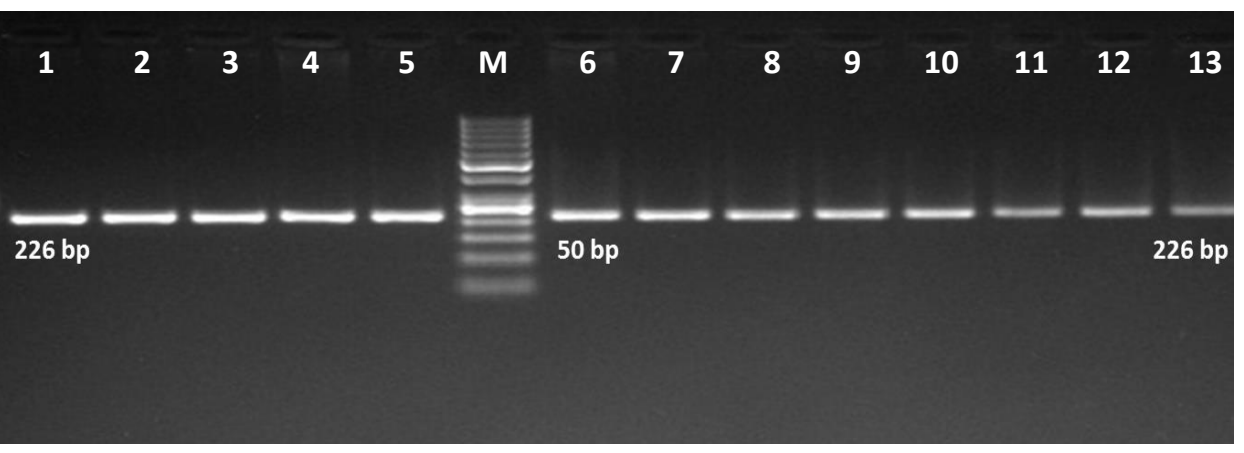

Figure 2: PCR amplification of Exon 3 + some part of intron 3 of IGF-1 gene in Karan Fries cow (M=50bp)

Lanes 1-15 = 226 bp 


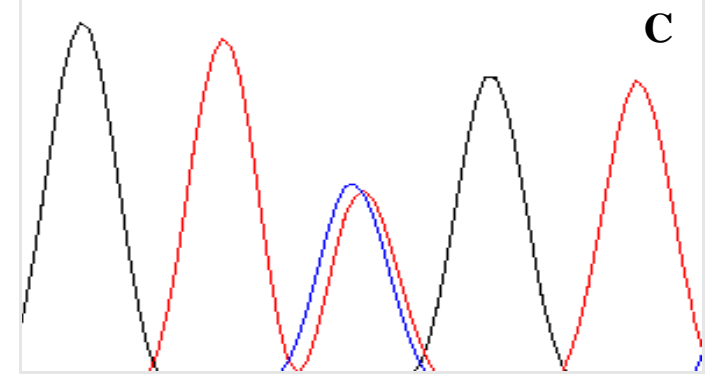

Bos taurus GGGCGTTGTCCTG

Karan Fries GGGCGTCGTCCTG
Bos taurus CATTGGCGATCTA

Karan Fries CATTGGTGATCTA

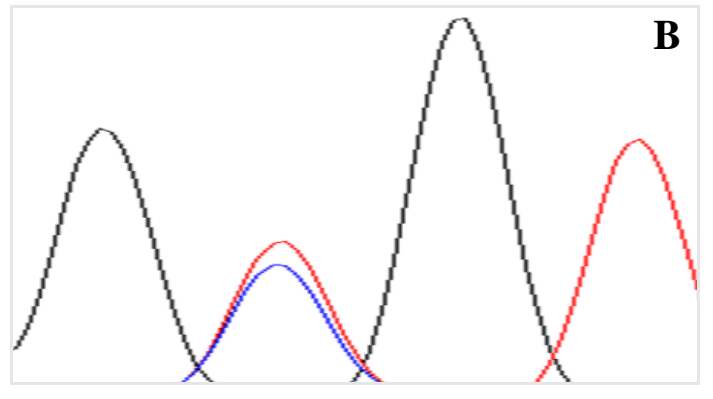

Bos taurus CTTGGGCGTTGTC Karan Fries CTTGGGTGTTGTC

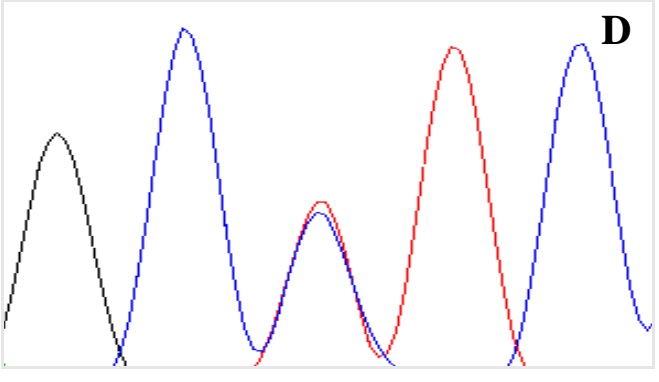

Bos taurus GGAAGCTTCCCTC Karan Fries GGAAGCCTCCCTC

370

371

372

373

374

375

376

377

378

379

380

381

382

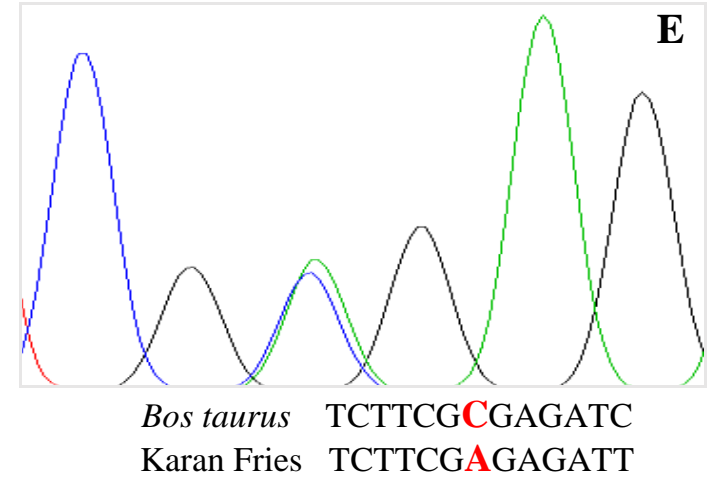

Bos taurus CGAGATCGGAGTT Karan Fries AGAGATTGGAGTT

Figure 3. Chromatogram and Clustal Omega alignment showing variation at position (A) rs29004508 (C>T), (B) rs29004509 (C>T), (C) rs29004510 (T>C), (D) rs29004511 (T>C) for Leptin gene and (E) rs133251968 (C>A), (F) rs137289661(C>T) for IGF-1 gene in Karan Fries cattle. 